\title{
Characteristics of Obstetric Patients at RSU Cut Meutia North Aceh During the 2020 Covid-19 Pandemic
}

\section{Iskandar}

Department of Obstetrics and Gynecology, Faculty of Medicine, Universitas Malikussaleh, Indonesia Email: iskandar.albin@unimal.ac.id

\begin{abstract}
:
Obstetrics is a medical science that specializes in the study of pregnancy and childbirth. This includes the process before during and after a woman gives birth. The scope of obstetrics includes, antepartum bleeding, postpartum hemorrhage, preterm pregnancy problems, complications in vaginal delivery, pregnancy with gastrointestinal disorders, hypertension in pregnancy, bleeding in the external and internal genitalia, and other diseases. Abortion was the most common disease group in this study, which was $71.4 \%$. Abortion is the termination of pregnancy before the fetus can live outside the uterus at the age of $<20$ weeks or weight $<500$ grams. The incidence of abortion is roughly estimated to be $15-20 \%$ and $80 \%$ occur in the first trimester. This research is a descriptive study with the research design used is a cross-sectional study conducted in the Obstetrics Inpatient Room at the Cut Meutia Hospital, North Aceh. The study was carried out in June 2021 with a population and sample of all patients in the Obstetric Inpatient Room at the Cut Meutia Hospital, North Aceh in 2020. The variables of this study were types of obstetric diseases based on the size group. Univariate analysis was used to describe the characteristics of the types of obstetric diseases that existed in the Obstetric Inpatient Room at the Cut Meutia Hospital North Aceh in 2020. The patients treated in the Obstetric Inpatient Room at the Cut Meutia Hospital North Aceh in 2020 were 244 patients. The percentage of antepartum bleeding was the highest group of diseases in the Obstetrics Inpatient Room at RSU Cut Meutia in 2020, while post-partum bleeding and bleeding in the external and internal genitalia were the least group of diseases. The second most common disease in the Cut Meutia General Hospital in 2020 was hyperemesis gravidarum, then premature rupture of membranes, followed by retained placenta, blighted ovum and preeclampsia.
\end{abstract}

Keywords:

obstretrics; patients; RSU Cut Meutia

\section{Introduction}

Obstetricsis a medical science that specializes in the study of pregnancy and childbirth. Thing this including process before during and after a woman gives birth. The scope of obstetrics between other, bleeding antepartum, bleeding postpartum, problem pregnancy premature, complications on vaginal delivery, pregnancy with gastrointestinal disorders, hypertension in pregnancy, bleeding on genitals external and internal diseases, and other diseases (Ulker, 2016). In this study, the most cases were found in the Obstetrics Inpatient Room of RSU Cut Meutia year 2020 isabortion. According to the World Health Organization (WHO) $15-50 \%$ of maternal deaths are caused by abortion. Complications of abortion in the form of bleeding or infection could cause death. That is why maternal deaths due to abortion often do not appear in death reports, but reported as bleeding or sepsis. An estimated 4.2 million abortions occur annually in Southeast Asia, with a breakdown of 1.3 million in Vietnam and Singapore, 155,000 to 750,000 in the Philippines and 300,000 to 900,000 in Thailand (Imbar, 2021). The incidence of abortion in Indonesia, spontaneous abortion is 
obtained as much as $10 \%-15 \%$ of 5 million pregnancies each year or $500,000-750,000$. Artificial abortion ranges from 750,000-1.5 million annually. This can be a reference for improving maternal health in Indonesia (Siregar, 2021). Based on data from the North Aceh Health Office in 2014, the maternal mortality rate in North Aceh was at the highest position in Aceh, however, that number fell in 2015 to only 11 cases, and increased back in 2016 amounted to 22 people. Generally, the prevalence of abortion is around $12 \%$ of all clinical signs of controlled pregnancy, but empirically estimates and prevalence still vary from the lowest $2-3 \%$ to the highest $30 \%$. The target proportion of the incidence of abortion in pregnant women is 15\% (Dinas Kesehatan Aceh, 2019).

WHO explained that abortion is a contributor to maternal mortality worldwide, because abortion can cause bleeding in pregnant women? Maternal mortality rate (MMR) is one of the important maternal health parameters. The maternal mortality rate is still a health problem in developing countries, especially in Indonesia. The incidence of spontaneous abortion is increasing, one of which is due to the age of pregnant women, especially in the primigravida group, which is included in the high-risk group. Maternal age has an influence on pregnancy and childbirth. The age of 20-35 years is a safe age for a mother to get pregnant, while the age of 35 years is included in the $4 \mathrm{~T}$ (4 Too) group, which is a group with pregnancies at risk of being too young and too old.5 The risk of abortion increases with increasing parity, increasing age. There are also other factors that influence the predisposition to repeated abortions. The probability of repeated abortion in a woman who has had three or more abortions. The second most common case after abortion in this study was hyperemesis gravidarum (HEG). WHO estimates that at least $15 \%$ of all pregnant women require trained obstetric care and otherwise the woman will experience serious and prolonged disability?

It was recorded that $45 \%$ of pregnant women experienced hyperemesis gravidarum (Kemenkes RI, 2016). The incidence of hyperemesis gravidarum has been worldwide with various incidence rates ranging from the United States, the prevalence rate reaches $2 \%$, Turkey $1.9 \%$, California $0.5 \%$, Sweden $0.9 \%$ and Indonesia the incidence rate reaches $1-3 \%$ of the total population. During pregnancy, the incidence of hypermesis gravidarum continues to increase until it reaches 15\% Indonesia Demographic and Health Survey (IDHS) recorded the incidence of hyperemesis gravidarum around $50 \%$ to $80 \%$ of pregnant women experience nausea and vomiting and approximately $5 \%$ of pregnant women require treatment for fluid replacement.

It was recorded that $45 \%$ of pregnant women experienced hyperemesis gravidarum (Kemenkes RI, 2016). The incidence of hyperemesis gravidarum has been worldwide with various incidence rates ranging from the United States, the prevalence rate reaches $2 \%$, Turkey $1.9 \%$, California $0.5 \%$, Sweden $0.9 \%$ and Indonesia the incidence rate reaches $1-3 \%$ of the total population. During pregnancy, the incidence of hypermesis gravidarum continues to increase until it reaches 15\% Indonesia Demographic and Health Survey (IDHS) recorded the incidence of hyperemesis gravidarum around $50 \%$ to $80 \%$ of pregnant women experience nausea and vomiting and approximately $5 \%$ of pregnant women require treatment for fluid replacement.

\section{Research Methods}

This research is descriptive research. The research design used was a cross-sectional study conducted in the Obstetrics Inpatient Room at the Cut Meutia Hospital, North Aceh. The study was carried out in June 2021 with a population and sample of all patients in the 
Obstetric Inpatient Room at the Cut Meutia Hospital, North Aceh in 2020. The variables of this study were the types of obstetric diseases divided into groups of antepartum bleeding, postpartum hemorrhage, preterm pregnancy problems, complications in vaginal delivery. Pregnancy with gastrointestinal disorders, hypertension in pregnancy, bleeding in the external and internal genitalia, and other diseases. The instrument used was patient book data in the Obstetric Inpatient Room at the Cut Meutia Hospital, North Aceh.

Inpatient Obstetrics Hospital Cut Meutia North Aceh in 2020. The data collected was analyzed statistically using computer software. The statistical analysis that will be used in this study is univariate analysis which can be used to describe the characteristics of the types of obstetric diseases in the Obstetrics Inpatient Room at the Cut Meutia Hospital, North Aceh in 2020.

\section{Discussion}

The disease groups in this study were divided into eight groups, including: antepartum bleeding group, postpartum hemorrhage, preterm pregnancy problems, complications in vaginal delivery, pregnancies with gastrointestinal disorders, hypertension in pregnancy, bleeding in the external and internal genitalia, and other diseases.

Table 1. Patient Characteristics Based on Age at Cut Meutia Hospital in 2020

\begin{tabular}{lcc} 
Respondent Age & Score & $\begin{array}{c}\text { \% } \\
(\mathbf{n = 2 4 4})\end{array}$ \\
\cline { 2 - 2 } Children (5-11 Years) & 1 & 0.4 \\
Adult (26-45 Years) & 170 & 69.7 \\
Elderly (46-65 Years) & 2 & 0.8 \\
Teenagers (12-25 Years) & $\underline{71}$ & $\underline{29.1}$ \\
\hline
\end{tabular}

Table 1 shows that the characteristics based on the age of the most respondents are aged 26-45 years with a total of 170 respondents $(69.7 \%)$, then youth $12-25$ years $(29.1 \%)$, elderly age 46-65 years $(2 \%)$ and children's age 5-11 year (1\%). Women of childbearing age based on the concept of the Ministry of Health are women of reproductive age, namely 15-49 years old, both married, widowed and unmarried.9,10 The number of fertile women (15-49 years) in Indonesia in 2018 was 70,715.59 people and Aceh Province as many as 1,434,559 person. These data strongly support this research, which is found that the adult age (26-45 years) is the age of the most respondents in obstetric diseases at the Cut Meutia Hospital in 2020 (Kementrian Kesehatan RI, 2018).

Table 2. Groups of Obstetric Patients Undergoing Cov-19 Screening in RSUD Cut Meutia 2020

\begin{tabular}{lccc} 
Cov-19 Screening & Score & & $\begin{array}{c}\text { \% } \\
(\mathbf{n = 2 4 4 )}\end{array}$ \\
\cline { 2 - 2 } D. Early Cov-19 & 119 & & 35.1 \\
NLR/ALC & 63 & & 18.6 \\
Antibody Swabs & 47 & \\
Not Screening Cov-19 & 110 & 32.9 \\
\hline
\end{tabular}

Table 2 shows that the patients who screened for the most Covid-19 were Early Detection of Covid-19 (35.1\%) and were not screened (32.4\%) and the least was by using antibody swab screening, namely $13.9 \%$. Filling out the Covid early detection form 19 has become an SOP (Standard Operating Procedure) that must be carried out by patients who will 
be treated in hospitals since the Covid-19 pandemic. 19 So that many patients in this study received screening for early detection of Covid-19. The form contains questions in the form of early symptoms of the disease caused by Covid-19.

The purpose of screening for early detection of Covid-19 is to find as early as possible the symptoms of the disease caused by the Corona Virus so that medical management can be carried out earlier since mild symptoms appear so that it is not expected to develop into moderate and severe symptoms (Pemerintah Kabupaten Muntilan, 2020). The number of patients who did not screen for Covid-19 in this study was dominated in early 2020, due to the first case of Covid-19 announced by the Indonesian government in March 2020.

The lowest screening is an antigen swab, this is because not all patients who are treated or visited have an antigen swab examination. Patients who come from the red zone or have at least one criterion for an epidemiological history and/or clinical symptoms will be subjected to a swab examination.

The high incidence even predicts more cases in Indonesia than recorded, because it is constrained by the limited availability of supporting examination facilities and diagnostic tests that are able to provide screening services for Covid-19 sufferers.

Table 3. Characteristics of Patients by Regency/City of Origin in Cut Hospital 2020

\begin{tabular}{lccc} 
Origin Regency/City & Score & & $\begin{array}{c}\mathbf{\%} \\
\mathbf{( n = 2 4 4 )}\end{array}$ \\
\cline { 2 - 2 } Aceh Besar & 1 & 0.4 \\
Aceh Tamiang & 1 & 0.4 \\
East Aceh & 21 & 8.6 \\
North Aceh & 184 & 75.4 \\
Really Merry & 3 & 1.2 \\
Bireuen & 5 & 2 \\
Lhokseumawe City & 27 & 11.1 \\
Langsa & 1 & 0.4 \\
Pidie Jaya & $\underline{1}$ & $\underline{0.4}$ \\
\hline
\end{tabular}

Table 3 shows that the frequency distribution of respondents by district/city is mostly from North Aceh with a total of 184 respondents (75.4\%), then Lhokseumawe City $(11.1 \%)$ followed by East Aceh (8.6\%).

North Aceh Regency covers 27 sub-districts and 852 gampongs with a total area of \pm $3,296.86 \mathrm{~km}^{2} .15$ The wide area coverage and distance that can be accessed by local residents is one of the reasons why many North Aceh residents visit RSU Cut Meutia. Access to a strategic location to Cut Meutia Hospital is very important in make it easier for patients to access health services. Location also determines the success of a hospital because location has a close relat ionship with patient welfare, especially JKN patients.

Table 4. Characteristics of Patients Based on How to Enter the Cut Meutia Hospital in Years 2020

\begin{tabular}{lcc} 
How to Enter & Score & $\begin{array}{c}\text { \% } \\
(\mathbf{n = 2 4 4 )}\end{array}$ \\
\cline { 2 - 2 } Come Alone & 116 & 47.5 \\
Aceh U. Reference & 113 & 46.3 \\
External Reference A & 15 & 6.1 \\
\hline
\end{tabular}


Most of the patients in this study came of their own accord, namely 116 patients (47.5 $\%$, followed by referrals from North Aceh $(46.3 \%)$ and the least was referrals from outside North Aceh (6.1\%). There are several factors that influence the decision to seek treatment for a person, namely the quality of services, treatment costs, facilities and decisions. Other studies also state that the location of treatment has a big influence on treatment decisions (Sari, 2013).

The referral system is held with the aim of providing quality health services, so that service goals are achieved without having to use expensive fees. The tiered referral system is one of the efforts made in strengthening primary services, as an effort to implement quality and cost control. Increasing cooperation in health facilities is one of the strategies to control the quality and cost of health services. North Aceh is the most referral hospital in this study because Cut Meutia Hospital is a North Aceh referral hospital that has cwide area coverage and distance that can be accessed by local residents.

Table 5. Characteristics of Patients Based on Occupation at Cut Meutia Hospital in Years 2020

\begin{tabular}{lcc} 
Work & $\begin{array}{c}\text { Score } \\
(\mathbf{n}=\mathbf{2 4 4})\end{array}$ & $\begin{array}{c}\text { \% } \\
(\mathbf{n}=\mathbf{2 4 4})\end{array}$ \\
\hline Midwife & 2 & 0.8 \\
Teacher & 2 & 0.8 \\
IRT & 193 & 79.1 \\
Student & 29 & 11.9 \\
Seamstress & 1 & 0.4 \\
Farmer & 5 & 2.0 \\
civil servant & 3 & 1.2 \\
Does not work & 1 & 0.4 \\
entrepreneur & 8 & 3.3 \\
\hline
\end{tabular}

Table 5 shows that from the results of research through medical records in the obstetric room of the Cut Meutia Hospital in 2020 based on job criteria, it was found that respondents as Housewives (IRT) were the largest group, namely 193 respondents (79.1\%). Tailors and respondents who do not work are the least number of respondents with 1 respondent $(0.4 \%)$.

Table 6. Distribution of Antepartum Bleeding Groups in Cut Meutia Hospital Tahun 2020

\begin{tabular}{lcc} 
Ante partum haemorrhage & $\begin{array}{c}\text { Score } \\
(\mathbf{n = 8 5})\end{array}$ & $\begin{array}{c}\text { \% } \\
(\mathbf{n = 8 5})\end{array}$ \\
\hline Abortion & 63 & 74.1 \\
Blighted Ovum & 10 & 11.8 \\
KET & 4 & 4.7 \\
Hydatidiform mole & 2 & 2.4 \\
Placenta Previa & 4 & 4.7 \\
Placenta Solution & 2 & 2.4 \\
\hline
\end{tabular}

The largest group of antepartum bleeding diseases in this study was abortion, as many as 63 patients $(74.1 \%)$ and the least were Hydatidiform mole and placental abruption $(2.4 \%)$. Abortion is the termination of pregnancy before the fetus can live outside the uterus at the age of $<20$ weeks or heavy body $<500$ grams. The incidence of abortion is roughly estimated to be $15-20 \%$ and $80 \%$ occur in the first trimester (Darmawati, 2011). Research conducted at Umi Barokah General Hospital Boyolali, found that the number of abortions in this study was dominated by incomplete abortions as many as 40 patients. Factors that influence the incidence of incomplete abortion are education, pregnancy distance, occupation and age $>35$ 
years.19 Not different from the research conducted at RSUD dr. Soeselo Slawi, Tegal Regency also showed that the incidence of incomplete abortion was the most $(77.7 \%)$ and was followed by imminent abortion (17.6\%) (Sholihah, 2018).

Hydatidiform mole, also known as molar pregnancy, is histologically characterized by chorionic villi abnormalities consisting of trophoblastic proliferation and villous stromal edema. The incidence of hydatidiform mole is increasing every year. This research is different from the research conducted at Prof. RSUP. Dr. RD Kandou Manado which showed high cases of Hydatidiform mole, as many as 35 cases with the most distribution in the age group 35 years $(33.3 \%)$. with the highest prevalence of 28 cases $(3.73 \%)$ (Nora, 2018).

Placental abruption is the separation of the placenta from its normal implantation site from the uterus, before the fetus is delivered. This occurs in pregnancies above 22 weeks or fetal weight above 500 grams. The incidence of placental abruption in this study is a small event, this study is in line with research conducted at the Palembang BARI Hospital in 20092011 which showed the cause of bleeding the least antepartum was placental abruption $(1.8 \%)$ (Pertiwi, 2015).

Table 7. Distribution of Post Partum Bleeding Groups in Cut Meutia Hospital Tahun 2020

\begin{tabular}{lcc}
$\begin{array}{l}\text { Post partum haemorrhage } \\
\text { Atonia }\end{array}$ & Score & $\begin{array}{c}\mathbf{\%} \\
\mathbf{( n = 4 )}\end{array}$ \\
\cline { 2 - 3 } & 2 & 50 \\
\hline$P H$ & $\underline{50}$
\end{tabular}

Table 7 shows that the distribution of the post partum bleeding group obtained the same number of two diseases, namely atony and $\mathrm{PPH}$ in each group there were 2 respondents $(50 \%)$.

Based on Aceh's health profile, the highest maternal mortality rate in Aceh province is in North Aceh District. In 2015 North Aceh took the first position in maternal mortality in Aceh province with 15 deaths. In 2016 there was an increase in deaths with a total of 26 cases, although in 2017 maternal mortality in North Aceh decreased by 18 cases and was ranked 2nd, but this is still a special concern (Aceh, 2015). Uterine atony can cause bleeding, the impact of bleeding is death, the occurrence of uterine atony is due to the myometrial fibers surrounding the blood vessels that vascularize the placental implantation area do not contract. Approximately $(75-80 \%)$ bleeding that occurs during the puerperium is caused by uterine atony.

Post partum bleeding often occurs in pregnant women who experience uterine atony. Maternal women who experience uterine atony are very susceptible to various complications, including post partum bleeding. In fact, according to Winkjosastro (2012), 90\% of postpartum hemorrhage is caused by uterine atony.

Table 8. Distribution of Groups of Obstetric Patients with Preterm Pregnancy Problems at Cut Meutia Hospital 2020

\begin{tabular}{lcc}
$\begin{array}{l}\text { Pregnancy problems } \\
\text { preterm }\end{array}$ & $\begin{array}{c}\text { Score } \\
(\mathbf{n}=\mathbf{2 7})\end{array}$ & $\begin{array}{c}\text { \% } \\
(\mathbf{n}=\mathbf{2 7})\end{array}$ \\
\hline Braxton Hiks & 2 & 7.4 \\
KPD & 20 & 74.1 \\
Preterm labor & 5 & 18.5 \\
\hline
\end{tabular}


The most common cause of preterm pregnancy problems in this study was PROM (74.1\%). Premature Rupture of Membranes (PROM) is a rupture of the membranes that occurs before the delivery process. Premature rupture of membranes occurs in about $1 \%$ of all pregnancies. Premature rupture of membranes causes $1 / 3$ of preterm births and is the cause of $18 \%-20 \%$ of perinatal morbidity and mortality (Andalas, 2019). This study is in line with research conducted at Arifin Achmad Hospital Pekanbaru, from the results of the study it was found that the biggest factors influencing preterm labor were caused by by Preeclampsia or eclampsia 68 cases (13.9\%) and amniotic fluid Early Rupture 55 cases (11.2\%) (Malita, 2012).

Another research conducted at RSUP. Prof. Dr. RD Kandou Manado in 2013, recorded 3,810 deliveries with 59 cases of KPD (1,54\%). In terms of fetal location and gestational age, most of the fetuses with head position and gestational age average term (Lowing, 2015).

Table 9. Distribution of groups of obstetric patients with complications during vaginal delivery at RSUD Cut 2020

\begin{tabular}{lcc}
$\begin{array}{l}\text { Complications on } \\
\text { vaginal delivery }\end{array}$ & $\begin{array}{c}\text { Score } \\
(\mathbf{n}=\mathbf{1 9})\end{array}$ & $\begin{array}{c}\mathbf{\%} \\
\mathbf{( n = 1 9} \\
)\end{array}$ \\
\hline $\begin{array}{l}\text { Partition is not } \\
\text { progressing }\end{array}$ & 2 & 10.5 \\
Retention of the placenta & 17 & 89.5 \\
\hline
\end{tabular}

Retention of the placenta is the most cases in the group of patients with vaginal complications, namely $89.5 \%$. Retention of the placenta is the unborn placenta until or after 30 minutes after the baby is born (Ramadhani, 2020). WHO states that one of the causes of bleeding after delivery is retained placenta? Retention of the placenta is a complication of childbirth in developing countries with 2-3\% of vaginal deliveries (Ulya, 2021). According to WHO, maternal mortality is $25 \%$ due to postpartum hemorrhage and $16-17 \%$ due to retained placenta. WHO 2008 data also explains that two-thirds of maternal deaths due to bleeding are of the type of retained placenta, it is reported that $15-20 \%$ of maternal deaths are due to retained placenta. According to reports in both developed and developing countries between $5 \%$ and $15 \%$. From this figure, it is found that retained placenta is in the third rank $(16-17 \%)$ after the first order of uterine atony (50-60\%) and the second is the remaining $23-24 \%$ of the placenta.

The results of the preliminary study obtained the maternal mortality rate in RSUD dr. H Bob Bazar SKM Kalianda in 2012 65/100,000 KH and 30.42\% caused by bleeding. Meanwhile, cases of retained placenta have an increasing trend in the last three years. In 2011 there were $42(15.9 \%)$ cases of retained placenta from 264 deliveries, in 2012 it increased to 52 $(19.3 \%)$ cases from 269 deliveries and in 2013 to $66(21.3 \%)$ cases out of 310 deliveries. The number of cases is greater than in RSUD Jendral Ahmad Yani Metro City, in 2012 there were 102 cases $(9.62 \%)$ of 1060 deliveries and in 2013 there were 48 cases (4.9\%) of 972 deliveries (Medical Record RSUD Jendral Ahmad Yani Metro City, 2012-2013) (Riyanto, 2015).

Retention of the placenta is caused by multiple factors, namely maternal factors, uterus and functional factors. Maternal factors consist of age, parity and anemia. Based on the results of a study in Southwestern Nigeria that the maternal age factor $>35$ years increases the risk 7 times to experience the incidence of retained placenta. The results of the study by Notikaratu, et al at Raden Mattaher Hospital Jambi showed that the factor of giving birth to multipara parity mothers had an 11 times risk of experiencing retained placenta (Riyanto, 2015). 
Another complication of vaginal delivery in this study was non-progressive parturition. One of the causes of death in mothers and also causes death in newborns is undeveloped parturition (where the parturition process is more than 18 hours). Undeveloped parturition on average in the world can cause maternal mortality by $8 \%$ and in Indonesia alone $9 \%$ of maternal deaths are caused by the incidence of undeveloped parturition. Inadvertent labor is one of the causes of maternal death because delayed delivery will cause infection, exhaustion when the mother strains, dehydration in the mother, and can also cause postpartum hemorrhage which is very dangerous for the safety of the mother (Riyanto, 2015).

Incidence of non-progressive parturition is a labor process which lasts more than 24 hours in mothers with primary pregnancies, and more than 18 hours in mothers with multiple pregnancies. In the second stage of labor, it is strongly influenced by three factors that play a very important role in which three things are the power to push the fetus out or known as (power) which includes his (uterine strength), contraction of the abdominal wall muscles, contraction of the diaphragm. and ligaments. The second factor is the fetal factor (passanger).

Including the size of the fetus, the weight of the newborn and others. The third factor that affects the delivery process is the birth canal (passage) which includes the pelvic bones, muscles, tissues, and ligaments. Age at the time the mother gave birth also had an effect on the delivery process. Maternal age less than 20 years and more than 35 years have a high risk which is likely to pose a threat to the health and life of the mother and fetus during pregnancy. Another factor is parity, a factor that determines the fate of the mother and fetus both during pregnancy and during delivery. In mothers with primiparas because they have never given birth, the possibility of abnormalities and complications is quite large.

Table 10. Distribution of Groups of Obstetric Patients with Gastrointestinal Disorders at the Cut Meutia Hospital in 2020

\begin{tabular}{lcc}
$\begin{array}{l}\text { Pregnancy with } \\
\text { gastrointestinal disorders }\end{array}$ & $\begin{array}{c}\text { Score } \\
(\mathbf{n}=\mathbf{4 5})\end{array}$ & $\begin{array}{c}\% \\
\mathbf{( n = 4 5}\end{array}$ \\
\cline { 1 - 2 } & & \\
GEA & $\underline{43}$ & 4.4 \\
HEG & $\underline{45.6}$ \\
\hline
\end{tabular}

Hyperemesis gravidarum is excessive nausea and vomiting in pregnant women to interfere with daily activities because of the patient's poor general condition due to dehydration. The cause of hyperemesis gravidarum is currently unknown and multifactorial. It is suspected that hormonal balance disorders such as HCG, estrogen, and progesterone, thyroxine, cortisol, are thought to be important causative factors. Some risk factors for hyperemesis gravidarum in previous pregnancies, mother or sister with hyperemesisgravidarum, multiple or twin pregnancy, hydatidiform mole, gestational age, maternal age that is too young, i.e., less than 20 years, primigravida, maternal occupation, adaptation and hormonal factors of pregnant women with anemia, psychological factors, vitamin deficiency, and obesity. 34 This study showed the prevalence of pregnancy with the most gastrointestinal disorders was hyperemesis gravidarum with 43 patients $(95.6 \%)$. The results of research conducted at Ujungberung General Hospital in 2011 illustrate that some patients who experience hyperemesis gravidarum aged 20-35 years are as many as $92.3 \%$, respondents aged 6-15 weeks as many as $92.3 \%$, and respondents who are multigravida as much as $55.4 \%$ (AR, 2012).

This study showed that the prevalence of pregnancy with the least gastrointestinal disorders was gastroenteritis, which was 2 patients (4.4\%). In line with research conducted at 
the Medan Sundari Hospital, out of 17 respondents, only 1 patient experienced problems with diarrhea $(5.9 \%) .34$

Table 11. Distribution of Hypertension Groups in Pregnancy at Cut Meutia Hospital 2020

\begin{tabular}{lcc}
$\begin{array}{l}\text { Hypertension in } \\
\text { pregnancy }\end{array}$ & $\begin{array}{c}\text { Score } \\
(\mathbf{n}=\mathbf{1 4})\end{array}$ & $\begin{array}{c}\mathbf{\%} \\
(\mathbf{n}=\mathbf{1 4}\end{array}$ \\
\hline $\begin{array}{l}\text { HELLP syndrome } \\
\text { Gestational hypertension }\end{array}$ & 2 & 14.3 \\
Preeclampsia & 2 & 14.3 \\
\cline { 1 - 1 } & $\underline{10}$ & $\underline{71.4}$ \\
\hline
\end{tabular}

World Health Organizationreported that hypertensive disorders accounted for $16 \%$ of all maternal deaths in developed countries, $9 \%$ of maternal deaths in Africa and Asia, and 26\% in Latin America and the Caribbean where the highest maternal mortality was due to eclampsia rather than preeclampsia. Globally, it is estimated that more than 4 million pregnant women experience preeclampsia each year, and every year an estimated 50,000-70,000 women die from preeclampsia. Research conducted by Martadiansyah et al revealed that in Indonesia the incidence of preeclampsia was in the second order which reached 128,273 events $(20.22 \%)$ which each year has increased to $9.42 \%$. Research by Yuniarti also revealed that the preeclampsia rate in East Java reached $36.29 \%$ of the total population 100,000 live births. Putri in her research found that in Jember Regency the incidence of preeclampsia reached 220 cases in 2017 and increased in 2018 to 284 cases of preeclampsia. $2.6 \%$, and those under 35 years of age only ranged from $2.2 \%$ to $2.3 \%$ (Imbar, 2021).

Preeclampsia is one of the health problems that often occurs in pregnancy (Rismawati, 2021). Preeclampsia is a pregnancy-specific syndrome that can affect any entire organ system characterized by hypertension and proteinuria. According to Berkane et al., preeclampsia is characterized by hypertension during pregnancy (systolic blood pressure of more than 140 $\mathrm{mmHg}$ or diastolic blood pressure of more than $90 \mathrm{mmHg}$ measured after the 20th week of gestation) and high protein levels (above $300 \mathrm{mg} / \mathrm{dL}$ ) in the urine. not only caused by one factor alone, but many factors that cause preeclampsia and eclampsia (multiple causation). History of preeclampsia, socioeconomic status, parity, diabetes mellitus, hydatidiform mole, multiple pregnancy, hydrops fetalis, Age over 35 years and obesity (Body Mass Index/BMI) are predisposing factors for the occurrence of preeclampsia. Sometimes pregnant women not aware of his condition who already suffers from preeclampsia.

Table 12. Distribution of Groups of Obstetric Patients with External and Internal Genital Bleeding at Cut Meutia Hospital 2020

\begin{tabular}{|c|c|c|}
\hline $\begin{array}{l}\text { Genital Bleeding external } \\
\text { and internal }\end{array}$ & $\begin{array}{l}\text { Score } \\
(\mathrm{n}=8)\end{array}$ & $\begin{array}{c}\% \\
(n=8)\end{array}$ \\
\hline Perineal rupture & 7 & 87.5 \\
\hline Ruptured labia & 1 & 12.5 \\
\hline
\end{tabular}

Bleeding in the genitalia in this study was mostly caused by rupture of the perineum $(87.5 \%)$ and the least was rupture of the labia $(12.5 \%)$. Perineal rupture is a perineal tear that occurs when the baby is born either spontaneously or by using a tool or action. Generally, perineal tears occur in the midline and can be extensive if the fetal head is delivered too quickly. The results of research conducted by Elisa et al. in 2015 showed that from 373 primiparous mothers, most of them experienced spontaneous perineal tears $84.9 \%$, and from 229 parity multiparous more than half experienced spontaneous perineal tears $62.4 \%$, whereas in grandemultipara mostly did not experience spontaneous perineal tears $94.4 \%$ (Endah, 2016). In another study it was stated that perineal rupture still occurs in low-risk maternity 
mothers, namely mothers with multiparas, productive age between 20-35 years, and infant weight $<4000$ grams, and in high-risk maternity mothers, namely mothers with birth spacing $<2$ years (Absari, 2017).

Table 13. Distribution of Other disease groups in the obstetric ward of RSUD Cut 2020

\begin{tabular}{|c|c|c|}
\hline Other diseases & Score & $\begin{array}{c}\% \\
(n=45)\end{array}$ \\
\hline Typhoid Fever & 1 & 2.4 \\
\hline DHF in pregnancy & 2 & 4.8 \\
\hline Endometritis & 1 & 2.4 \\
\hline Fetal distress & 1 & 2.4 \\
\hline $\begin{array}{l}\text { Deep bronchial asthma } \\
\text { pregnancy }\end{array}$ & 2 & 4.8 \\
\hline Hepatitis in pregnancy & 2 & 4.8 \\
\hline $\begin{array}{l}\text { Hyperthyroidism of } \\
\text { pregnancy (grave's } \\
\text { disease) }\end{array}$ & 1 & 2.4 \\
\hline UTI & 1 & 2.4 \\
\hline IUFD & 4 & 9.5 \\
\hline Place the star & 1 & 2.4 \\
\hline Place the breech & 3 & 7.1 \\
\hline Febris Obstetrics & 7 & 16.7 \\
\hline Premature Parturition & 4 & 9.5 \\
\hline Spontaneous Partition & 2 & 4.8 \\
\hline $\begin{array}{l}\text { Vaginal bleeding } \\
\text { ec trauma }\end{array}$ & 1 & 2.4 \\
\hline Post date & 3 & 7.1 \\
\hline Previous SC & 4 & 9.5 \\
\hline Iminens uterine rupture & 2 & 4.8 \\
\hline
\end{tabular}

The results of this study showed that the most patients who experienced febrile observation in the other categories were 7 patients (16.7\%), and the fewest were typhoid fever, endometritis, fetal distress, hyperthyroidism of pregnancy, urinary tract infection (UTI), latitude, vaginal bleeding, each of which was 1 event $(2.4 \%)$. Pregnant women who experience fever with body temperature $>38^{\circ} \mathrm{C}$ during pregnancy is a serious problem. High fever can be symptoms of infection in pregnancy. Fever can be caused by infection in pregnancy, namely the entry of pathogenic microorganisms into the body of a pregnant woman which then causes signs or symptoms of the disease. Severe infections can cause symptoms in the form of fever and impaired vital organ function. Infection can occur during pregnancy, childbirth and the puerperium.41 Research conducted by Intan et al. showed that pregnant women diagnosed with falciparum malaria experienced symptoms of chills and a body temperature of 37.6oC (Rehana, 2017).

The low incidence of UTI in pregnant women in this study is different from the results of a study conducted by Alvie et al which stated the incidence of UTI was $30.2 \%$, with the most symptoms being unable to hold back when wanting to urinate and the most common gestational age was at 28 gestational ages. -40 weeks (Gusrianty, 2016).

Latitude events in this study are also among the fewest occurrences. Research conducted at the Islamic Hospital A. Yani Surabaya stated that there was a relationship between parity and cross-sectional pregnancy at the Surabaya Maternity Clinic. From the results of the study, it was concluded that pregnant women who have high parity tend to have 
position abnormalities. Therefore, pregnant women must often control the content so that early detection of abnormalities can be carried out and can be treated quickly.

Fetal distress or fetal distress in this study was the least occurrence (2.4\%). Fetal distress was defined as progressive fetal hypoxia and/or acidemia secondary to inadequate fetal oxygenation. This term is used to denote changes in the fetal heart pattern, reduced fetal movement, obstruction fetal growth, and the presence of meconium at delivery. The results of Muhammad's research (2016) showed that the indications that caused the incidence of sectio caesarea (SC) were $18(20.7 \%)$ fetal position abnormalities, the highest was due to fetal distress as many as $25(28.7 \%)$ and the lowest was due to fetal distress. birth of twins as much as 2 $(2.3 \%)$ (Daryanti, 2020).

\section{Conclusions}

Patients treated in the Obstetric Inpatient Room of Cut Meutia General Hospital North Aceh in 2020 as many as 244 patients who were divided into groups of antepartum bleeding, postpartum hemorrhage, preterm pregnancy problems, complications in vaginal delivery, pregnancy with gastrointestinal disorders, hypertension in pregnancy, bleeding on the external and internal genitalia, and other diseases. The percentage of antepartum bleeding was the highest group of diseases in the Obstetrics Inpatient Room at RSU Cut Meutia in 2020, while post-partum bleeding and bleeding in the external and internal genitalia were the least group of diseases. Abortion is the most common problem in pregnancy in the Obstetrics Inpatient Room at RSU Cut Meutia in 2020. The second most common disease is hyperemesis gravidarum.

\section{References}

Absari, Y. \& Shanti, E. F. A. (2017). Faktor- Faktor yang Mempengaruhi Kejadian Rupture Perineum pada Persalinan Normal di BPM Wayan Witri Sleman Yogyakarta.

Adhyatma. Komplikasi Kehamilan. (2019). Rehana, I., Mutiara, H., Kedokteran, F. \& Lampung, U. Penatalaksanaan Malaria dalam Kehamilan. Medula Unila 7, 41-45 (2017).

Adit. (2019). Hubungan Antara Paritas dengan Kehamilan Letak Lintang di Rumah Sakit Islam A. Yani Surabaya. Fac. Nurs. Midwifery.

Andalas, M., Maharani, C. R., Hendrawan, E. R., Florean, M. R. \& Zulfahmi, Z. (2019). Ketuban pecah dini dan tatalaksananya. J. Kedokt. Syiah Kuala 19, 188-192.

AR, A. C. Y. (2012). Hubungan Antara Karakteristik Ibu Hamil dengan Kejadian Hiperemesis Gravidarum di RSUD Ujung Berung Periode 2010- 2011. Univ. Islam Bandung 3.

AR, F. S. D. (2021). Hubungan Konsumsi Nutrisi Harian Ibu Hamil dengan Tingkat Preeklamsia di Puskesmas Panti Kabupaten Jember. 3, 6.

Arifsa R. (2018). Adaptasi Sistem Gastrointestinal pada Ibu Hamil dengan Obesitas di Rumah Sakit Sundari Medan. Skripsi Srarjana 115.

Anwary, S. D. dan A. Z. (2020). Analisis Faktor Risiko Abortus di Klinik Bidan Praktek Swasta Hj. Gunarti Banjarbaru.

Darmawati. (2011). Mengenali Abortus Dan Faktor Yang Berhubungan Dengan Kejadian Abortus. Idea Nurs. J. 2, 12-18.

Daryanti, D. \& Aprilina, H. D. (2020). Gambaran Yang Mempengaruhi Fetal Distress Pada Sectio Caesarea di RSUD Banyumas. Adi Husada Nurs. J. 6, 59.

Dinas Kesehatan Aceh. Profil Kesehatan Aceh Tahun 2019. (2019). Dinas Kesehat. Aceh 53, 1-85. 
Departemen Kesehatan Republik Indonesia. Profil Kesehatan Indonesia tahun 2015. Badan Penelit. Dan Pengemb. Kesehat. Kementeri. Kesehat. RI (2016).

Dr. Sampurna, M. K. \& dr. Shelly Tjahyadewi, Sp. THT., M. K. (2020). Hubungan Disomsia dengan Gambaran Klinik Pasien yang Terkonfirmasi Covid-19.

Endah, S. N. (2016). Relationship Beetwen Parity and the Occurrence of Spontaneous Perineal Tears at Normal Labor. J. Nurse Int. 2, 147- 157.

Fakultas Kedokteran Indonesia. (2015). Kapita selekta penatalaksanaan rutin obstetri ginekologi dan keluarga berencana.

Farid, M. F. \& Gosal, F. A. (2017). Faktor- faktor yang Mempengaruhi Pemilihan Metode Kontrasepsi pada Wanita Usia Subur (WUS) di Desa Selassae Kecamatan Bulukumpa Kabupaten Bulukumba Provinsi Sulawesi Selatan. JST Kesehat. 7, 381-388.

Febriani, M. \& Syamsiah, S. (2020). Hubungan Preeklampsia Berat Dengan Kejadian Berat Badan Lahir Rendah (BBLR). 1-20.

Firdaus, K. K. et al. (2020). Panduan teknis pelayanan rumah sakit. J. ARSI 5, 1689-1699.

Gusrianty, A. R., Astuti, S., Hartinah, H. \& Susanti, A. I. (2016). Angka Kejadian Gejala Infeksi Saluran Kemih Pada Ibu Hamil Di Desa Mekargalih Kecamatan Jatinangor Kabupaten Sumedang Tahun 2014. J. Sist. Kesehat. 1, 71-75.

Imbar, A.W.J., and Nagib, F. A. (2021). Relationship Between Maternal Age and Preeclampsia. Kieraha Med. J. 3, 41-46.

Kemenkes RI. Causes of Hyperemesis Gravidarum Israini. J. Kebidanan 10, 103-108 (2016).

Kementrian Kesehatan RI. (2018). Data Informasi Profil Kesehatan Indonesia 2018. J. Chem. Inf. 53, 1-1699.

Lowing, J. G. A., Lengkong, R. \& Mewengkang, M. (2015). Gambaran Ketuban Pecah Dini Di Rsup Prof Dr. R. D. Kandou Manado. e-CliniC 3, 1-4.

Maita, L. (2012). Faktor Ibu yang Mempengaruhi Persalinan Prematur di RSUD Arifin Achmad Pekanbar. J. Kesehat. Komunitas 2, 31-34.

Nanda Putri Ramadhani, W. S. S. (2020). Hubungan Antara Karakteritik Pasien dengn Kejadian Retensio Plasenta pada Pasien yang dirawat di Rumah Sakit Al-Ihsan Bandung Periode 1 Januari 2010-31 Desember 2020. Pros. SNaPP2011 Sains, Teknol. dan Kesehat.

National Population and Family Planning Board (BKKBN), Statistics Indonesia (BPS), M. of H. \& (Kemenkes), and I. Indonesia Demographic and Health Survey 2017. 588 (2018).

Nora, H. \& Khalishah, G. (2018). Gambaran Jenis Penyakit Ginekologi di Rumah Sakit Umum Daerah Dr. Zainoel Abidin Banda Aceh Tahun 2017. 1, 22-31.

Nurchairin, N. (2018). Hubungan Overdistensi Uterus dengan Kejadian Atonia Uteri pada Ibu Post Partum di Sebuah Rumah Sakit di Provinsi Lampung. J. Ilm. Keperawatan Sai Betik 13, 215.

Ratnasari, H. M. (2020). Hubungan Antara Usia Ibu Hamil dan Kejadian Abortus Spontan Studi Analitik Observasional pada Pasien Primigravida di RSI Sultan Agung Semarang Periode Januari 2013 - Desember 2018.

Rismawati, R., Notoatmodjo, S. \& Ulfa, L. (2021). Faktor Risiko Terjadinya Preeklamsia Ibu Bersalin. J. Bid. Ilmu Kesehat. 11, 24-33.

Riyanto. (2015). Faktor Risiko Kejadian Retensio Plasenta pada Ibu Bersalin di RSUD Dr. H. Bob Bazar, SKM Kalianda. Kesehat. Metro Sai Wawai VIII.

Riza Fahmi, Arifah Devi Fitriani, I. M. (2020). Analisis faktor-faktor yang memengaruhi kunjungan pasien jkn di poli rawat jalan rsud dr. fauziah bireuen. 2, 1-12.

Siregar, S., Amelina, N. \& Netri, Y. (2021). Hubungan kadar hemoglobin dengan kejadian abortus. Jambura J. Heal. Sci. Res. 3.

Paputungan, T. V., Wagey, F. W. \& Lengkong, R. A. (2016). Profil penderita mola hidatidosa di RSUP Prof. Dr. R. D. Kandou. J. e-Clinic 4, 215-222. 
Pemerintah Kabupaten Muntilan. (2020). SPO Pengisian Form Deteksi Dini Covid-19 Bagi Petugas 2020.

Pertiwi, J. L. (2015). Distribusi Karakteristik Perdarahan Antepartum pada Kehamilan yang Diselesaikan dengan Seksio Sesarea di RSUD Palembang Bari Tahun 2009-2011.

Pitriani, R. (2013). Faktor-Faktor yang Berhubungan dengan Abortus Inkomplit di Rumah Sakit Umum Daerah Arifin Achmad Provinsi Riau. J. Kesehat. Komunitas 2, 83-87.

Putri, L. P. M. V., Wiradnyana, A. A. G. P. \& Darmayasa, I. M. (2019). Karakteristik ibu hamil dengan hiperemesis gravidarum di RSUP Sanglah Denpasar tahun 2017. Intisari Sains Medis 10, 177-179.

RPI2JM Bidang Cipta Karya Kabupaten Aceh Utara Tahun 2015 - 2019. Profil Kabupaten Aceh Utara. 9-37 (2021).

Sari, P. C. P. (2013). Faktor-Faktor Yang Mempengaruhi Keputusan Berobat Serta Dampaknya Terhadap Kepuasan Pasien.

Sholihah, L. M. (2018). Gambaran Karakteristik Kejadian Abortus Di Rumah Sakit Umum Umi Barokah Boyolali. Keperawatan 12.

Ulker, K. \& Kivrak, Y. (2016). The effect of information about gynecological examination on the anxiety level of women applying to gynecology clinics: A prospective, randomized, controlled study. Iran. Red Crescent Med. J. 18.

Yadul Ulya, Susilia Idyawati, N. H. A. (2021). Faktor Umur dan Paritas terhadap Kejadian Retensio Plasenta. Indones. J. Midwifery 4, 51-56. 